\title{
A Horse, Hippopotamuses and the Polish Rule of Law
}

\author{
Jacek Kurczewski ${ }^{1}$
}

Published online: 5 November 2019

(c) The Author(s) 2019

An old Polish encyclopaedia edited several times by the Reverend Chmielowski in the mid-18th century is mostly known for its peculiar definition of a horse: "A horse is, that which everyone sees". ${ }^{1}$ This definition became proverbial even if the above-cited sentence was merely the start of a lengthy listing of many interesting breeds-Turkish, Spanish, Samogitian, etc., followed by notorious individual examples of the class ostensibly denoted as Bucephalus or a "Horse in Ruthenia, 36 years of age, of which 27 years have been as a working horse and then living at the House of his Grateful Lord". Even so, the opening statement in those days of global horsepower made sense and ought to be treated as a hidden ostensive definition pointing at a representative of the class in question, especially with regard to the Ruthenian Bucephalos. It therefore comes as no surprise that from the very first moment I was enchanted by the way my friend Martin Krygier approached the description of the rule of law in his very influential 1990 paper feeling the need to supplement the extensive description of two basic elements of the rule of law with two examples. One is an example of the rule of law ideal fulfilled. This is the PM Whitlam dismissal case. All Australians remember, I presume, that in 1975 their PM Gough Whitlam was dismissed by HM Governor General Sir William Kerr. As Martin wrote, there are certainly reasons to assume that Whitlam, an experienced politician, had considered all possible ways to remain in power. However, when discovering that the Governor General had already taken the decision, instead of calling Her Majesty, Whitlam then surrendered. Whitlam entered the new parliamentary elections and lost but these facts bear no relation to the case itself. The PM acknowledged the legal right of the General Governor to act as he had done. Martin's Hungarian Marxist friend could not understand such a low posture while for Krygier it was a clear example of the Rule of Law. The Rule of Law is what everyone sees in Whitlam's dismissal case. Critics of the Reverend Chmielowski's definition of a horse do not realise that there is subtle logic in that the entry "Horse" is immediately followed by the entry on "Seahorse", this time defined in the more conventional way

\footnotetext{
1 Chmielowski (1755: 574).
}

Jacek Kurczewski

j.kurczewski@uw.edu.pl

1 Institute of Applied Social Sciences, University of Warsaw, Warsaw, Poland 
(in those days it was difficult to find members of the Polish gentry or the clergy who were familiar with the beast) as "an animal enjoying [both] sea and land" similar in posture to the English bulldog but with an equine head, very opulent and fat, covered with hairless hard thick skin but with a hairy tail. ${ }^{2}$ Here is a horse and there is his opposite: the seahorse. Similarly, the role of the exotic beast in Krygier's 1990 tale is played by the transitional Afghan Communist government: in 1979 the Soviet government asked the then Afghan PM Mohammed Taraki to dismiss his deputy Hafizullah Amin and to nominate Babrak Karmal instead. However, at the cabinet meeting in the presence of the Soviet Ambassador, Amin shot Taraki and became the Prime Minister. He then began a bloody purge of his opponents and invited the Soviet Army to intervene against the opposition and was himself killed. Whatever Krygier writes about the basic features of the rule of law does not really matter, the examples are just as self-evident as a horse was for a Pole in the 18th century. "We have thus a contrast between society in which the law matters in the public life and the society in which—shortly speaking - the law does not exist at all ${ }^{3}$ ".

The diminution of the Rule of Law, as we may call it, was something obvious to those experienced in Communist, National-Socialist or other forms of totalitarian rule. Not surprisingly, for us this is just as difficult to describe as describing a horse was for the Reverend Chmielowski. When writing on the Rule of Law in 1989 at the beginning of the period of transition I could only deal with history, foreign experiences and general statements. I had no real Polish example to demonstrate. It took 5 years of the democratisation of the formerly communist Poland to come to what looks like a good example of the rule of law: I refer to the presidential elections in 1995. Lech Wałęsa, the hero of the Solidarność movement and the first generally elected President of Poland, was suddenly defeated by the young leader of the reformist wing of the Communist Party, Aleksander Kwaśniewski. In the second run on 19th November 1995 Kwaśniewski received 51.72\% of the votes while Wałęsa received 48.28\%. Political tension was at its peak, as some were afraid that the victorious former Communist would initiate a return to communist rule, whatever form that would take in 1995. Apart from the normal small-scale electoral fraud-accusations that tend to accompany elections in every normal democratic country-Wałęsa's side had pointed to the false electoral information provided by Kwaśniewski who claimed that he had received University-level education. It transpired that although Kwaśniewski had been a student at the University of Warsaw and was also the leader of the Communist students' union, the SZSP, he had never completed his University education and had not graduated. The case was sent to the Supreme Court which decided on 9 December 1995 that-despite the evident misinformation on the part of Kwaśniewski-it was impossible to prove or disprove whether the difference of more than 600,000 votes had been swayed by such misinformation, as already after the first run all major media in Poland had informed the public about the doubts concerning Kwaśniewski's education. The verdict was by no means unanimous- 12 votes for, 5 votes against; the reasons for this decision, as

\footnotetext{
2 Chmielowski (1755: 576).

3 Krygier (1990)
} 
we shall see, were controversial, but the decision was binding. ${ }^{4}$ Binding only legally, we should add, as anything could have occurred as long as President Wałęsa and his ministers were still in power. Notwithstanding these circumstances Wałęsa recognised the verdict as binding and gave up his office to his successor. The constitutional crisis had been averted, the rule of law reigned in Warsaw and the subsequent presidential election results were confirmed as valid by the unchallenged verdicts of Poland's Supreme Court including in 2015 when President Komorowski lost to Andrzej Duda who had been nominated by the "Law and Justice" (PiS) Party which had been in government since the autumn of 2015.

A clear counter-example is what happened in the country around 20 years after Kwaśniewski's election case. On March 92018 the Constitutional Tribunal of Poland reached a verdict concerning the constitutionality of the new law on the Tribunal (Article 188 of the Constitution states, inter alia, 'the conformity of statutes and international agreements with the Constitution' is to be decided by the Tribunal) and it found that it was unconstitutional. On the same day the verdict was sent to the PiS Prime Minister Beata Szydło to be published in accordance with Article 190 of the Constitution. ${ }^{5}$ The verdict was not published, however, as it was issued much later according to the personal decision of the PM. This abuse of the highest law of the country was repeated in subsequent cases until the composition of the Tribunal was changed with the aid of unconstitutional legislation. As everyone can see, it sometimes occurs that horses have to give way to hippopotamuses!

For many of us this was the end of the Rule of Law in Poland. Unless, that is, we care for the qualifications which had already been made by Krygier in his 1990 paper. He wrote that the Rule of Law had "nowhere been fully implemented" (Krygier 1990: 52). It seems as if he was assuming that this was the ideal of what Lon Fuller-following Aristotle-would call the morality of aspirations. This is a dramatic conclusion. In making a distinction between the morality of aspirations and the morality of duty Fuller ascertains that criminal law belongs to the binary world of crime-not crime that allows us to punish the criminals. One cannot punish a poet or a cook who has not attained his ideal. This is a very convincing argument against criminalising a failure to achieve the ideal of the Rule of Law, just as any other aspiration. With such an assumption even Law and Justice politicians can then claim immunity. The Rule of Law is thus the ideal to be realised, but it is only an ideal. Before WW2 and since the 1980s Polish law has had the Tribunal of State which is constitutionally mandated by the President and its highest executives are

\footnotetext{
4 III SW 1102/05. https://www.infor.pl/akt-prawny/DZU.1995.144.0000708,uchwala-sadu-najwyzszeg o-o-waznosci-wyboru-prezydenta-rzeczypospolitej-polskiej-dokonanego-w-dniu-19-listopada-1995-r. html (retrieved 01/08/2019).

5 Article 190

1. Judgments of the Constitutional Tribunal shall be of universally binding application and shall be final.

2. Judgments of the Constitutional Tribunal regarding matters specified in Article 188, shall be required to be immediately published in the official publication in which the original normative act was promulgated. If a normative act has not been promulgated, then the judgment shall be published in the Official Gazette of the Republic of Poland, Monitor Polski.
} 
subject to the possible sanction of withholding their right to vote and to run in elections as well as a ban on holding public office in the future. Such a mostly "moral" sanction may be applied against those who have not fulfilled the 'ideal'. The fact that nobody in office after 1989 had been sentenced by the Tribunal might be used as argument for thesis that since 1980s nobody in Poland in top public offices abused the law, or that such an abuse was never taken seriously. The latter would mean that between 1995 and 2016 there was not at all a Rule of Law in Poland.

However, it would be wise for the old Polish encyclopaedia to check whether there is more than one breed of hippopotamus, so to say, or rather more than one type of the diminution of the Rule of Law. Krygier (1990) points to the variations in the Rule of Law, assuming a basic similarity within totalitarian realm. However, the significance that he-rightly - attaches to the local culture and tradition needs to take the local variations of both the Rule of Law and the limitations on the Rule of Law into account. Let us take the case of Poland into account once again. Historically, the Polish-Lithuanian Commonwealth or Res Publica was based upon the principle of the basic equality of the ruling gentry. This is Aurea Libertatis as glorified by the Reverend Chmielowski, by the Polish gentry "demos" as well as by serious political writers of that time. Let us observe that the element of equality for all had also been stressed by A. V. Dicey when he pointed out that the rule of law means "the equal subjection of all classes to the ordinary law of the land administered by the ordinary law courts" (Dicey 1962: 202). Chmielowski quoted to the same effect the authoritative statement by Tęczyński who said: "Haec est vera libertatis, in qua aequali iure omnes se contimemtur imparantes sibi, et prosint aliis". Another Polish thinker, Stanislaw Orzechowski, wrote in 1543 that "Law is the Lord in the free Kingdom". The Polish equivalent of the Act of Habeas Corpus-a privilege Neminem captivabimus nisi iure dictum - had been granted by the Polish King in 1430 (although it needs to be stressed that only in 1791, a year before the end of the Old Res Publica, was it extended to the burghers). The ideology of a noble democracy was expressed in the triad: Freedom-Equality-Law as 'non Rex regnat sed Lex'. Of course it was as democratic as Athens in that only the upper estate, comprising around $10 \%$ of the population, actually had all three prerogatives at their disposal. So it is difficult to say what the Polish tradition is, the dominant ideology of the dominant sector of society or-especially since the sixteenth century-the serfdom, exploitation and arbitrary personal power of landlords over the majority of the then numerically prevailing peasantry and farm labourers. At the same time, the formal equality within the Polish gentry coincided with the drastic internal stratification and prevalence of the large landowners who had been able to bribe the small gentry electorate and to mock court decisions. The Polish historian of legal culture in old Poland, Władysław Łoziński, called his book Prawem i lewem (Either Rightly or Like a Crook) and, in my opinion, such an attitude best characterises the Polish popular legal culture up until today (Kurczewski 2007). One exploits the law when it is expedient to do so but one tries to go around the law whenever this is feasible. Martin tended to write kindly about the rule of law in pre-war Poland as the courts functioned properly although after the unconstitutional coup by Marshall Józef Piłsudski in 1927, democracy and the Rule of Law were limited (for instance, by special courts hearing certain types of cases and extra-parliamentary law-making) until the German/Soviet 
invasion of Poland in 1939 and the new 1935 Constitution, which had been adopted unconstitutionally, undermined the division of powers although the independence of the judiciary was maintained. Political pluralism and parliamentary institutions had been put under the direct control of the executive. By no means had pre-war Poland become a totalitarian state like its Western and Eastern neighbours, but a specific kind of semi-authoritarianism had been institutionalised thereby lamentably limiting not equality before the law but the freedom of public expression and action. This is why the old Polish conjunction of all three components of Aurea Libertatis: freedom, law and equality_-this time offered to everybody_-seems to represent the ideal to be used as a measure of achievement.

Open Access This article is distributed under the terms of the Creative Commons Attribution 4.0 International License (http://creativecommons.org/licenses/by/4.0/), which permits unrestricted use, distribution, and reproduction in any medium, provided you give appropriate credit to the original author(s) and the source, provide a link to the Creative Commons license, and indicate if changes were made.

\section{References}

III SW 1102/05. UCHWAŁA SĄDU NAJWYŻSZEGO z dnia 9 grudnia 1995 r. o ważności wyboru Prezydenta Rzeczypospolitej Polskiej dokonanego w dniu 19 listopada 1995 r. https://www.infor.pl/ akt-prawny/DZU.1995.144.0000708,uchwala-sadu-najwyzszego-o-waznosci-wyboru-prezydenta -rzeczypospolitej-polskiej-dokonanego-w-dniu-19-listopada-1995-r.html. Accessed 01 Aug 2019

Chmielowski B (1755) Nowe Ateny albo Akademia [...]. Jesuits College Publishing, Lwów

Dicey AV (1962) Introduction to the study of the law of the constitution. Macmillan, London (1914)

Krygier M (1990) Rządy prawa: kulturowe osiągnięcie o znaczeniu uniwersalnym. Res Publica 12:50-53

Kurczewski J (2007) Prawem i lewem Kultura prawna społeczeństwa polskiego po komunizmie. Studia Socjologiczne 2:33-60

The Constitution of the Republic of Poland (1997) The Constitution of the Republic of Poland of 2nd April, 1997 as published in Dziennik Ustaw No. 78, item 483 https://www.constitution.org/cons/ poland/konse.htm. Accessed 01 Aug 2019

Publisher's Note Springer Nature remains neutral with regard to jurisdictional claims in published maps and institutional affiliations. 